\title{
Perceptions and expectations of pregnant women about the type of birth
}

\author{
Percepções e expectativas de gestantes sobre o tipo de parto \\ Percepciones y expectativas de mujeres embarazadas sobre el tipo de parto
}

\section{Roberta Marielle Arik' \\ ORCID: 0000-0002-7855-9619}

Cristina Maria Garcia de Lima Parada' ORCID: 0000-0002-9597-3635

Vera Lúcia Pamplona Tonete' ORCID: 0000-0002-3620-7519

Fernanda Cristina Manzini Sleutjes" ORCID: 0000-0002-7825-8568

'Universidade Estadual Paulista Julio de Mesquita Filho. Botucatu, São Paulo, Brazil.

"Faculdade Sudoeste Paulista. Avaré, São Paulo, Brazil.

How to cite this article:

Arik RM, Parada CMGL, Tonete VLP, Sleutjes FCM. Perceptions and expectations of pregnant women about the type of birth. Rev Bras Enferm. 2019;72(Suppl 3):41-9. doi: http://dx.doi.org/10.1590/0034-7167-2017-0731

\section{Corresponding Author:}

Cristina Maria Garcia de Lima Parada E-mail: cristina.parada@unesp.br

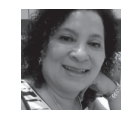

Submission: 10-23-2017 Approval: 04-21-2018

\begin{abstract}
Objective: to understand the perceptions and expectations of pregnant women about the type of birth. Method: this is a qualitative research, based on the assumptions of the Humanization of Obstetric Care. 15 pregnant women were interviewed twice at the beginning and the end of gestation between October 2015 and May 2016. Data were analyzed according to the method of the Discourse of the Collective Subject. Results: the discourses were associated with four themes: Advantages of vaginal birth over cesarean section; Fear and unpredictability of vaginal birth; Importance of the doctor in the definition of the type of birth; and Influence of family and friends in choosing the type of birth. Final considerations: according to pregnant women, vaginal birth has more benefit compared to cesarean section. However, during gestation and birth, fear of pain and the unexpected, and medical opinions of friends and family against vaginal birth strongly influence the choice of cesarean section.

Descriptors: Pregnant Women; Parturition; Humanization of Assistance; Nursing; Qualitative Research.
\end{abstract}

\section{RESUMO}

Objetivo: apreender as percepções e expectativas de gestantes sobre o tipo de parto. Método: trata-se de pesquisa qualitativa, que tomou por base os pressupostos da Humanização da Assistência Obstétrica. Entre outubro de 2015 e maio de 2016, 15 gestantes foram entrevistadas duas vezes, no início e final da gestação. Os dados foram analisados segundo o método do Discurso do Sujeito Coletivo. Resultados: os discursos apreendidos associaram-se a quatro temas: Vantagens do parto vaginal sobre a operação cesariana; Medo e imprevisibilidade do parto vaginal; Importância do médico na definição do tipo de parto; e Influência da família e amigos na escolha do tipo de parto. Considerações finais: para as gestantes, o parto vaginal apresenta benefício em comparação à operação cesariana. Contudo, durante a gestação e nascimento, o medo da dor e do inesperado e opiniões médicas, de amigos e familiares contrárias ao parto vaginal, influenciam fortemente a opção pela operação cesariana.

Descritores: Gestantes; Parto; Humanização da Assistência; Enfermagem; Pesquisa Qualitativa.

\section{RESUMEN}

Objetivo: entender las percepciones y expectativas de mujeres embarazadas sobre el tipo de parto. Método: se trata de una investigación cualitativa, que se basó en los presupuestos de la Humanización de la Asistencia Obstétrica. Entre octubre de 2015 y mayo de 2016, 15 mujeres embarazadas fueron entrevistadas dos veces al inicio y final de la gestación. Los datos fueron analizados según el método del Discurso del Sujeto Colectivo. Resultados: los discursos incautados se asociaron a cuatro temas: Ventajas del parto vaginal sobre la operación cesárea; Miedo e imprevisibilidad del parto vaginal; Importancia del médico en la definición del tipo de parto; Influencia de la familia y amigos en la elección del tipo de parto. Consideraciones finales: para las mujeres embarazadas, el parto vaginal presenta beneficio en comparación a la operación cesárea. Sin embargo, durante una gestación y nacimiento, o parecer médico inesperado, de amigos y familiares con parto vaginal, fuertemente influenciado por el funcionamiento de la cirugía cesárea.

Descriptores: Mujeres Embarazadas; Parto; Humanización de la Atención; Enfermería; Investigación Cualitativa. 


\section{INTRODUCTION}

Birth is a phenomenon intrinsically related to women and their families, becoming a social practice and, as such, its meaning goes through historically determined changes. Until the nineteenth century, birth was considered ritual performed by midwives in households. With the creation of hospitals, at the end of this century, this event was gradually institutionalized; a change that has given it new meanings, transcending from the physiological, family and female events to the medical act ${ }^{(1-3)}$.

From then on, the role of the parturient was replaced by that of the medical professional for whom the driving was granted and all the decisions regarding parturition. Cesarean birth began to be used on a large scale, often as a routine procedure, without any obstetric indication necessary for its accomplishment ${ }^{(2)}$, little recognizing the importance of the emotional aspects and the interference of the external environment in the process of labor and birth. There is favor to the interventionist action of this professional, besides the overvaluation of techniques and technologies in a process of alienation of the woman, family and society ${ }^{(1)}$.

Currently, cesarean section is considered a common procedure, with evidence that its choice is strongly influenced by partners, family, friends and the media, where vaginal birth is often presented in a negative way. The idea of the safety provided by the cesarean section contravenes anxiety and fear of vaginal birth, justifying the desire of pregnant women for this type of birth, with the support of family members, especially of their mothers and companions who often end up guaranteeing the procedure payment ${ }^{(4)}$. A research carried out in a private medical center in northern Taiwan has shown that the medical professional can play a decisive role in choosing the cesarean section, either by presenting it as an option from the beginning of gestation, and by responding to the passive acceptance of the pregnant woman, or for supposedly leading to shared decision-making throughout gestation ${ }^{(5)}$. In Brazil, a qualitative study carried out with women who experienced both vaginal birth and cesarean section showed ambivalence of feelings: in vaginal labor, difficulty in labor as opposed to ease in recovery, being the inverse for cesarean section. Vaginal birth was also reported as fast, simple, practical and healthy, whereas cesarean section was described as complicated and associated with negative events, although it allows birth planning ${ }^{(2)}$.

Cesarean section's performance, on demand, is associated with the pregnant woman's high schooling, higher family income and, consequently, greater access to technology. Mostly, doctors do not contradict this desire, which contributes to the high rates of the procedure, often decided at the beginning of prenatal care ${ }^{(6)}$. On the other hand, vaginal birth may not occur, even when desired, due to the lack of orientation of the pregnant women on their evolution or even by the valorization of the possible complications of this type of birth ${ }^{(5)}$.

Global recommendations for care in prenatal care include the development of educational actions with groups of women with the goal of promoting improvements in maternal and newborn health. Taking advantage of the opportunity to discuss doubts and wishes of pregnant women is important, offering concise information, identifying the needs in a timely manner and, therefore, the search for solutions ${ }^{(7)}$.
In an emancipatory perspective, among the professionals of different health sectors, nurses are shown as strategic agents to share technical-scientific knowledge inherent to the prenatal and birth period with the pregnant women, as well as to address the emotional aspects that these women and their families can live in these periods. The present study was proposed in order to deepen the knowledge about the factors influencing the choice by type of birth and to what extent they are present during the pregnancy-puerperal cycle. It aims to obtain subsidies to enable these educational actions, recognizing the necessary autonomy of pregnant women in the option for the type of birth appropriate to their obstetric condition and their concept. Identification and analysis of these influences, from the perspective of pregnant women, are fundamental to subsidize effective educational practices, with the intention of qualifying and changing the model of care for birth.

\section{OBJECTIVE}

To understand the perceptions and expectations of pregnant women about the type of birth.

\section{METHOD}

\section{Ethical aspects}

This research was approved by the Research Ethics Committee of the Faculdade de Medicina de Botucatu and met all norms foreseen for research in humans.

\section{Theoretical-methodological framework}

The principles of Humanization of Obstetric Care were used as a theoretical framework, considering that its precepts are related to the improvements in the follow-up of women throughout the pregnancy-puerperal cycle. Humanization of Obstetric Care is a primary condition for adequate follow-up of the birth and puerperium, based on aspects such as the reception and care of women, her family members and newborns with dignity by the Health Care Network (Rede de Atenção à Saúde) and the adoption of beneficial measures in the follow-up of birth and birth, avoiding interventionist and often unnecessary practices, leading to greater risks for the woman and the newborn ${ }^{(8)}$.

The Discourse of the Collective Subject (DCS) method was applied to the collected data, favoring the expression of the respondents' thinking, starting from systematic and standardized procedures. Initially, Key Expressions (KE) were identified as continuous or discontinuous pieces of speech, selected by the researcher for revealing the essence of the content of the testimony. Such expressions are fundamental parts for the construction of DCS, since they possess the essence of thought, as it appears in discourses, excluding nonessential thoughts. Then, the selected KE were grouped from the Central Ideas $(\mathrm{Cl})$, statements that translate the essential of the discursive content present in the testimonies of the social actors. Finally, the DCS were constructed. For this, the synthesis-based discourses were composed in the first person singular, considering the KE and 
the $\mathrm{Cl}$ of the individual discourses, by convergence between them and seeking to contemplate the proposed objective ${ }^{(9)}$.

\section{Type of study}

This study is characterized as a prospective field study, with a qualitative approach, research modality indicated to the study of the experiences and the interpretations that the individuals make with respect to the feelings and thoughts involved ${ }^{(10)}$.

\section{Methodological procedures}

Intentionally, they were invited to participate in this research: pregnant women under follow-up in a public service of a municipality in São Paulo countryside, as well as participants of the Prenatal Guidance Group of the same municipality that also embrace pregnant women served by the private health network.

Data collection was performed by one of the authors, a nurse working in the primary care network of said municipality and a master's degree course in Nursing Postgraduate from a public university in the same geographic region. This researcher presented previous experience in the application of a semi-structured interview, a data collection strategy chosen for allowing access to the data of reality, from the perspective of the informant, since he is given the freedom necessary to address the study questions $^{(9-11)}$. There were two moments of interview: the first (M1), before the $20^{\text {th }}$ week and the second (M2), after the $35^{\text {th }}$ week of gestation. The only inclusion criterion was related to gestational age, which should allow inclusion in the study in the first half of pregnancy.

All participants were given information about the research, about the objectives and way of collecting data. There were no refusals and, thus, the day and time for $\mathrm{M} 1$, between October and December 2015, were scheduled. The second interview took place between February and May 2016, contemplating the same M1 pregnant women.

All interviews were carried out at the participants' residence, in a reserved space, with a duration ranging from 35 to $45 \mathrm{~min}$ utes. Two voice recording devices were used and the recorded material was transcribed in its entirety. The guiding question was: "Talk about the type of birth you want (M1)". At M2, this was repeated and two other issues were included: "Have you changed your mind? Why?"In the search for varied testimonials, phrases were used to encourage the interviewees' speech:"Tell me more about it", "What do you think about this subject?" or "Tell me more about your ideas". At the two moments, after the interview, the recording was presented to the pregnant woman, requesting completeness and/or correction of the recorded content, when necessary.

Alternatively, information on the type of birth performed was obtained on the woman's first return to the postpartum health unit for the neonatal screening test called the Heel-Stick test and the baby's vaccination.

The final number of 15 participants was established during the development of the research and considered the possibility of obtaining enough data to respond both the proposed objective and theoretical saturation point: a conceptual tool used in qualitative research in the different fields of Health, in order to establish the moment for interruption in the capture of new components ${ }^{(10)}$. Participants were identified with the letter $P$ (pregnant woman) and numbers from 1 to 15 to protect their anonymity, according to the order of interviews.

\section{Data analysis}

The data obtained in the interviews were systematized according to the Discourse of the Collective Subject method, being discussed in the light of the Humanization of Obstetric Care premises. Speeches were associated with four themes: Advantages of vaginal birth over cesarean section; Fear and unpredictability of vaginal birth; Importance of the doctor in the definition of the type of birth; and Influence of family and friends in choosing the type of birth. Data were codified by the interviewer who also transcribed them in full, counting on the contribution of the other authors in the analysis performed.

\section{RESULTS}

The 15 participants were characterized by their mean age of 27.5 years, ranging from 18 to 37 years. All had a partner at the time of data collection and more than eight years of school approval and, predominantly, did not exercise paid employment, but among those who exercised, were mentioned the professions: maid, nanny, janitor and footwear. Regarding the obstetric history, nine women were primigravidae, three had undergone an abortion and three had a history of a cesarean section. Regarding the current gestation, 13 pregnant women were attended in the public service, in Basic Health Units and two in private medical practices.

Among the participants interviewed in M1, eight (P1-P3, P10$\mathrm{P} 13$ and $\mathrm{P} 15)$ reported the desire to perform vaginal birth, five (P4-P5, P7-P9) expressed preference for cesarean section and two $(P 6, P 14)$ had doubt about the type of birth. At M2, there were no doubts as to the type of birth desired: eight pregnant women (P1, P4-P5, P7-P10, P14) preferred cesarean section and seven (P2-P3, P6, P11-P13, P15).

There are few changes with regard to the desired birth in the two moments of interview (M1 and M2). Regardless the type of birth chosen, most participants maintained the same desire throughout pregnancy: vaginal (P2-P3, P11-P13, P15) or cesarean section (P4-P5, P7-P9) and between the two pregnant women with doubts in early pregnancy, one mentioned desire for vaginal birth and the other for cesarean section at the end of pregnancy. Of the seven women who mentioned that they wished for vaginal birth at the end of gestation, five underwent cesarean section. None who mentioned desire for cesarean section in M2 had vaginal birth. Summary of the place of prenatal care, type of birth desired and justification in the two interview moments, is shown in Chart 1, as well as the birth actually performed with justification.

Perceptions and expectations during the gestation regarding the type of birth desired are presented, considering the moment of data collection (M1 or M2) and separated by themes that aggregate the DCS constructed, with the respective $\mathrm{Cl}$. 
Chart 1 - Prenatal, type of birth desired in Moments 1 and 2 and the performed, with the respective justifications, Botucatu, São Paulo, Brazil, 2016

\begin{tabular}{|c|c|c|c|c|c|c|c|}
\hline & \multirow[b]{2}{*}{ Prenatal } & \multicolumn{2}{|r|}{ M1 } & \multicolumn{2}{|r|}{ M2 } & \multirow{2}{*}{$\begin{array}{c}\text { Birth } \\
\text { performed }\end{array}$} & \multirow[b]{2}{*}{ Justification } \\
\hline & & $\begin{array}{l}\text { Birth } \\
\text { desired }\end{array}$ & Justification & $\begin{array}{l}\text { Birth } \\
\text { desired }\end{array}$ & Justification & & \\
\hline P1 & $\begin{array}{l}\text { Public/ } \\
\text { private }\end{array}$ & Vaginal & $\begin{array}{l}\text { Low risk, fast recovery, it favors } \\
\text { the baby. }\end{array}$ & $\begin{array}{l}\text { Cesarean } \\
\text { Section }\end{array}$ & Safety, medical influence. & $\begin{array}{l}\text { Cesarean } \\
\text { Section }\end{array}$ & $\begin{array}{l}\text { Doctor-pregnant } \\
\text { woman decision }\end{array}$ \\
\hline P2 & Public & Vaginal & $\begin{array}{l}\text { Fast recovery, it respects baby's } \\
\text { time. }\end{array}$ & Vaginal & $\begin{array}{l}\text { It favors baby and suckling, fast } \\
\text { recovery. }\end{array}$ & $\begin{array}{l}\text { Cesarean } \\
\text { Section }\end{array}$ & Macrosomia \\
\hline P3 & Public & Vaginal & Fast recovery, short hospitalization. & Vaginal & Various benefits, fast recovery. & $\begin{array}{l}\text { Cesarean } \\
\text { Section }\end{array}$ & Fear of pain \\
\hline P4 & $\begin{array}{l}\text { Public/ } \\
\text { private }\end{array}$ & $\begin{array}{l}\text { Cesarean } \\
\text { Section }\end{array}$ & $\begin{array}{l}\text { Cesarean section safety did not } \\
\text { dilate in the } 1 \text { st gestation. }\end{array}$ & $\begin{array}{l}\text { Cesarean } \\
\text { Section }\end{array}$ & $\begin{array}{l}\text { Fear of induction of vaginal birth and } \\
\text { pain. }\end{array}$ & $\begin{array}{l}\text { Cesarean } \\
\text { Section }\end{array}$ & $\begin{array}{l}\text { Doctor-pregnant } \\
\text { woman decision }\end{array}$ \\
\hline P5 & Public & $\begin{array}{l}\text { Cesarean } \\
\text { Section }\end{array}$ & Fear of vaginal birth, practicality. & $\begin{array}{l}\text { Cesarean } \\
\text { Section }\end{array}$ & Fear of vaginal birth. & $\begin{array}{l}\text { Cesarean } \\
\text { Section }\end{array}$ & $\begin{array}{l}\text { Doctor-pregnant } \\
\text { woman decision }\end{array}$ \\
\hline P6 & Public & Doubt & $\begin{array}{l}\text { Previous cesarean birth, benefits of } \\
\text { vaginal birth }\end{array}$ & Vaginal & Healthy, fast recovery. & Vaginal & $\begin{array}{l}\text { Fast and tranquil } \\
\text { evolution }\end{array}$ \\
\hline P7 & $\begin{array}{l}\text { Public/ } \\
\text { private }\end{array}$ & $\begin{array}{l}\text { Cesarean } \\
\text { Section }\end{array}$ & $\begin{array}{l}\text { Fear of vaginal birth, influence of } \\
\text { friends. }\end{array}$ & $\begin{array}{l}\text { Cesarean } \\
\text { Section }\end{array}$ & $\begin{array}{l}\text { Fear of vaginal birth, practicality, } \\
\text { medical influence. }\end{array}$ & $\begin{array}{l}\text { Cesarean } \\
\text { Section }\end{array}$ & $\begin{array}{l}\text { Doctor-pregnant } \\
\text { woman decision }\end{array}$ \\
\hline P8 & Public & $\begin{array}{l}\text { Cesarean } \\
\text { Section }\end{array}$ & Previous pelvic surgery. & $\begin{array}{l}\text { Cesarean } \\
\text { Section }\end{array}$ & Pelvic problems. & $\begin{array}{l}\text { Cesarean } \\
\text { Section }\end{array}$ & $\begin{array}{l}\text { Doctor-pregnant } \\
\text { woman decision }\end{array}$ \\
\hline P9 & Private & $\begin{array}{l}\text { Cesarean } \\
\text { Section }\end{array}$ & Bad experience with vaginal birth. & $\begin{array}{l}\text { Cesarean } \\
\text { Section }\end{array}$ & $\begin{array}{l}\text { Bad experience with vaginal birth, } \\
\text { safety. }\end{array}$ & $\begin{array}{l}\text { Cesarean } \\
\text { Section }\end{array}$ & $\begin{array}{l}\text { Doctor-pregnant } \\
\text { woman decision }\end{array}$ \\
\hline P10 & $\begin{array}{l}\text { Public/ } \\
\text { private }\end{array}$ & Vaginal & Several benefits. & $\begin{array}{l}\text { Cesarean } \\
\text { Section }\end{array}$ & Fear of vaginal birth, security. & $\begin{array}{l}\text { Cesarean } \\
\text { Section }\end{array}$ & $\begin{array}{l}\text { Doctor-pregnant } \\
\text { woman decision }\end{array}$ \\
\hline P11 & Public & Vaginal & $\begin{array}{l}\text { Low risk, understanding pain, fast } \\
\text { recovery. }\end{array}$ & Vaginal & $\begin{array}{l}\text { Fear of cesarean section, influence of } \\
\text { natural practices. }\end{array}$ & $\begin{array}{l}\text { Cesarean } \\
\text { Section }\end{array}$ & $\begin{array}{l}\text { Pressão arterial } \\
\text { aumentada }\end{array}$ \\
\hline P12 & Public & Vaginal & Low risk, several benefits. & Vaginal & $\begin{array}{l}\text { It favors the baby, fast recovery, risk of } \\
\text { infection after cesarean section. }\end{array}$ & $\begin{array}{l}\text { Cesarean } \\
\text { Section }\end{array}$ & Medical decision \\
\hline P13 & Public & Vaginal & Low risk, several benefits. & Vaginal & $\begin{array}{l}\text { Fast recovery, short hospitalization, risk of } \\
\text { infection after cesarean section. }\end{array}$ & Vaginal & $\begin{array}{l}\text { Pregnant } \\
\text { woman's } \\
\text { decision }\end{array}$ \\
\hline P14 & Private & Doubt & $\begin{array}{l}\text { Benefits of vaginal birth, practicality } \\
\text { of cesarean section. }\end{array}$ & $\begin{array}{l}\text { Cesarean } \\
\text { Section }\end{array}$ & $\begin{array}{l}\text { Fear of vaginal birth pain, low risk, } \\
\text { practicality. }\end{array}$ & $\begin{array}{l}\text { Cesarean } \\
\text { Section }\end{array}$ & $\begin{array}{l}\text { Doctor-pregnant } \\
\text { woman decision }\end{array}$ \\
\hline P15 & Public & Vaginal & $\begin{array}{l}\text { Fast recovery, short hospitalization, } \\
\text { fear of cesarean section. }\end{array}$ & Vaginal & $\begin{array}{l}\text { Risk of infection after cesarean section, } \\
\text { short hospitalization, facilitates care. }\end{array}$ & $\begin{array}{l}\text { Cesarean } \\
\text { Section }\end{array}$ & Medical decision \\
\hline
\end{tabular}

\section{Theme 1. Advantages of vaginal birth over cesarean section}

\section{First Moment - M1}

It is identified in DCS 1 and 2, the preference of the pregnant women for vaginal birth, justified by its advantages, such as natural birth, transient pain and fast recovery of the mother, allowing better care for the baby.

DCS 1: so the type of birth / want is the vaginal birth, sincelalways had that desire, even before I became pregnant, I already thought: "when I get pregnant, I want to have vaginal, at least it only hurts at the time". We have the baby and it gets easier, the body comes back faster, $w$ stays only one day in the hospital and we are already walking. I prefer a thousand times to feel the pains of the contraction and then to be well! God willing, it's going to be natural. (Cl 1-Vaginal birth only hurts at the time and recovery is fast. Interviews: P1-P3, P10-P13, P15)
DCS 2: I prefer to have vaginal birth because it is more natural. It's baby time! It's easier, quicker, it's just good things ... Had the baby [the baby] today, practically tomorrow you can leave, you can do your things, you can take better care of the child. I think on this side, for being able to be more calm to take care of the baby. (Cl 2- I prefer vaginal birth because it is more natural and allows better care for the baby. Interviews P1-P3, P10- P13, P15)

Cesarean section is contemplated in DCS 3 as a last option, only with accurate medical indication, and the fear feeling is revealed associated with its accomplishment.

DCS 3: I'm very afraid of the cesarean because you have to stay in the hospital for three days, at rest, with the stitches, you risk getting bacteria and infections because of the cut and we cannot gain weight. It's not cool, I'm really scared. So, only as the last resort, in the case of not being born, or having any complications... (CI 
3- Cesarean section only as the last resort. Interviews: P1-P3, P10-P13, P15)

\section{Second Moment - M2}

It is observed in DCS 4 the maintenance of the preference for vaginal birth in relation to cesarean section, still due to the rapid recovery, the lower risk of infection and respect for the baby's time. In DCS 5, the possibility of cesarean section is verified, if necessary, in the presence of complications or risks.

DCS 4: I still want vaginal labor. It's all easier: the recovery is faster, they say that labor takes time, but recovery is immediate, and there are no complications. You have the baby [in one day] and the other can leave, you can take better care of the baby. So I give preference to this, it is healthier and has no risk of infection. It's the time the child wants to be born, it's nature, its moment... It has everything to be vaginal [birth] and has less risks for both me and the baby. (Cl 4- I still want vaginal birth because of its advantages. Interviews: P2-P3,P6, P11-P13, P15)

DCS 5: you have to try vaginal birth and if there is any complication, last minute, or if you do not come, you have a cesarean section. If you do not risk, I think vaginal birth is worth a try! ( $\mathrm{Cl} 5$ - You have to try vaginal birth, unless there is some complication. Interviews: P3, P11-P13, P15)

\section{Theme 2. Fear and unpredictability of vaginal birth}

\section{First Moment - M1}

The fear of pain during vaginal birth remains portrayed in the speeches obtained and, according to the DCS6, such pain is seen as necessary for the birth, being compensated by the arrival of the baby.

DCS 6: I'm afraid of the pain, because everyone says that the pain of birth is bad. I guess it's strong; it should not be colic.... But at the same time that I feel that pain, I will think that it is to have my baby, which it will be worth it! (Cl 6- I am afraid of the pain, but for my baby it's worth having vaginal birth. Interviews: P2, P10-P11, P15)

In addition to pain, waiting, unexpected and unpredictable at the time of birth may be identified as potential generators of insecurity, a feeling that often influences choices in favor of birth by cesarean section, as highlighted in DCS 7.

DCS 7: I believe that every woman should be afraid of both the vaginal birth and the cesarean, because you do not know what will happen ... I prefercesarean because I will not feel pain at the time, I will feel it later... Vaginal hurts a lot before, I'm afraid of pain, of contractions, afraid of something happening to me as much as to the child. The class says that it takes hours to have the baby with vaginal birth, it stays there with pain, in the serum, I do not know... The fear that makes me prefer the cesarean section... (Cl 7- I'm afraid, several things can happen at birth time. Interviews: P4-P6, P7, P9, P14)

\section{Second Moment - M2}

It is observed in DCS 8 that there is concern about labor at the end of gestation, regarding waiting time and other difficulties, whereas DCS 9, on the other hand, reveals a positive attitude related to the pain of vaginal birth, including by the availability of non-pharmacological methods of their relief.

DCS 8: I am afraid of not having dilation, of delaying and suffering, especially the baby being born late... I think that when you become a mother, you care more about them than with us ... There are people who are already afraid and choose cesarean. I do not! I want to try [vaginal birth]! (Cl 8- I'm afraid to suffer, but I'll try vaginal birth. Interviews: P2-P3, P6, P11-P12, P15)

DCS 9: the pain, I do not care, because I already know it will hurt, but I think it is bearable... I will not be the first to have vaginal [birth] and, in the old days, I did not have a cesarean, they were all [births] vaginal. Today, the hospital has a pool, balls ... It's cool! So, you have to try. For me, it will be better, I am alone and the stitches [cesarean section] can disrupt. (CI 9-The pain is bearable and I will not be the first to have vaginal birth. Interviews: P2-P3, P6)

\section{Theme 3. Importance of the doctor in the definition of the type of birth}

\section{First Moment - M1}

In DCS 10 and 11, the possibility of a shared decision with the doctor regarding the type of birth was observed.

DCS 10: vaginal birth is healthier for pregnant women, recovery is fast, but say the pain is very strong. In cesarean, the problem is that there are days with pain, that boring little pain to stand up, because she has the stitches. So I still have questions, I want to talk to the doctor to see what we decide. (Cl 10- My doctor and I have not yet decided the type of birth. Interviews: P6, P14)

DCS 11: everything I alright. I've already talked to him [doctor], I want to have a C-section, and he agreed. He said to sign a term that I want on my own, that it is not the doctor who is forcing. I asked if he objected to not doing [vaginal birth] and he said he had no problem at all, just sign the term that there is no problem with cesarean section. ( $\mathrm{Cl} 11-$ I want cesarean section and the doctor agreed. Interviews: P4- P5, P7-P9)

\section{Second Moment - M2}

The unpredictable feeling of labor may lead to the choice of cesarean section at the end of pregnancy. Sometimes a decision is shared or even encouraged by the doctor, as can be identified in the DCS 12 and 13.

DCS 12: I would be heading for vaginal birth, but now I've decided to have a C-section. I talked to the doctor and he made me feel safe for the cesarean section. It's all right! I hope [the baby] comes on time... ( $\mathrm{Cl} 12-$ The doctor convinced me to have a cesarean. Interviews: P1, P- P5, P7- P10, P14)

DCS 13: I chose the cesarean because it was more relaxed, the doctor thought it more appropriate, for health, even. At SUS I would have to try vaginal [birth] and, if I did not "give it", then I would have a cesarean ... It is very risky! The doctor thinks I might pass out at the time and something will happen to me or to the baby. If it's not the C-section, I can risk my life and my daughter! If it was the 
real vaginal, quiet birth, I wanted to ... But I will not be suffering, inducing the birth, I do not want, not at all ... So, everything is right, it will be C-section! ( $\mathrm{Cl} 13-$ It has to be cesarean so as not to have risks. Interviews: P1, P4-P5, P7-P10, P14)

\section{Influence of family and friends in choosing the type of birth}

\section{First Moment - M1}

In DCS 14, the decisive role of people in the conviviality of pregnant women is observed, in the choice of the latter by type of birth.

DCS 14: when I got pregnant, I wanted it to be vaginal, I wanted to try, it was my dream to have a vaginal birth. It's very different, natural, you feel everything ... But, they kept saying many things, that I could not ... Then I had that... (Cl 14-They talked a lot against vaginal birth. Interviews: P4, P7, P9)

In particular, family members play an important role in any decision-making process on the type of birth. In DCS 15, clear family support emerges as to the chosen route of birth: vaginal birth; while the DCS 16, the familiar induction to the cesarean section.

DCS 15: family always supports and is always close to us ... My husband supports me a lot and says, "do whatever you want". My mother had children in vaginal birth and she said that it is good. He said that it is not that pain that the people talk about, that it is not a pain that is not bearable. So they support! (Cl 15- I have support from my family for having vaginal birth. Interviews: P1-P3, P11)

DCS 16: my mother is concerned. She says she prefers cesarean so I will not suffer. I think she imagines that cesarean section is less suffering than vaginal birth ... My husband says "No way you are going to have vaginal [birth], you gotta have a C-section!" Because if you want to, he pays... (Cl 16- My mother and my husband prefer cesarean section. Interviews: P2, P10, P15)

\section{Second Moment - M2}

It should be noted that good stories and experiences with vaginal birth can positively influence the choice for this type of birth. These aspects are set out in DCS 17.

DCS 17: everyone wants me to have a vaginal birth, my family and my husband support what I decide... My mother supports, she advises, because she had me and my sister vaginal [birth]. She says that recovery and getting used to the child is better. I'm calm, I think everything is going to work out. ( $\mathrm{Cl} 17$ - I have family support in the decision for vaginal birth. Interviews: P2-P3, P6, P11- P13, P15)

By contrast, at the end of pregnancy, the family members' perception of the fragility of the pregnant woman may influence in favor of the cesarean section, as can be seen from DCS 18.

DCS 18: from my mother I do not have support to have vaginal birth. When I did the ultrasound he [the baby] was of the right size and weight, but my mother said, "how are you going to have vaginal birth?" My husband also wants cesarean, he says like this: "I want to see at the time, if you will" (CI 18- My family thinks I cannot handle vaginal labor. Interviews: P2, P15)

\section{DISCUSSION}

It was possible to understand, in this study, the pregnant women's perceptions and expectations regarding the type of birth desired, revealing the aspects that were considered and the ones that defined the birth performed, being often pointed out the advantages of vaginal birth, especially for the baby; the fear of pain related to labor and the unpredictability of vaginal labor; and the valorization of the doctor's and family's indication as to the type of birth.

The choice for vaginal birth is justified in studies, especially for its advantages such as: being natural, healthy, fast recovery and providing greater autonomy for self-care and care with the newborn ${ }^{(2,5,12-14)}$ reasons according to what was learned in the statements of the pregnant women, since the discourses point out the advantages of vaginal birth, related to the rapid recovery and quality of the relationship with the baby in the postpartum period, identified as aspects that make vaginal birth better for the mother and the baby.

A study conducted in West Africa identified factors related to lower satisfaction with cesarean section, such as slower recovery, emotional, social and economic impact, presented mainly by women from less favored economic classes, due to the less support for the accomplishment of the domestic tasks and difficulties related to care with the newborn ${ }^{(15)}$.

It was verified in the discourses recognition of the pregnant women about the disadvantages of cesarean section, mainly due to the dependence of the family members on the routine activities, caused by the slow recovery in the postpartum, due to the pain in the incision and the presence of the surgical stitches, factors associated with difficulties in mother-child care.

Fear of pain during labor proved to be a frequent feeling in speeches. Among other possibilities of Humanized Obstetric Care, the support for pain relief offered to women can be physical and/ or emotional, transmitting safety to the parturient, from sharing on the evolution of labor and the use of non-pharmacological techniques, such as warm baths and the use of Swiss ball, among others, always respecting the physiological limits of each woman and ensuring that, on request, pharmacological pain relief methods are used ${ }^{(2,16)}$. In addition, relaxation techniques may reduce the behavioral reactions present in labor, such as stress and anxiety over pain, including the adoption of comfortable postures in quiet and well-lit environments ${ }^{(17-18)}$.

It is understood from the speeches that the difficult recovery and the pain in the postpartum were the main negative questions related to cesarean section and pointed out by the pregnant women. On the other hand, pregnant women who preferred this type of birth corresponded to the perception that vaginal birth was often associated with unnecessary suffering, spared by cesarean section, evidencing the model of medical-centered care ${ }^{(19)}$. Similarly, a study conducted in Germany showed that the decision by cesarean section is justified by fear of vaginal birth, concern with the child and association of cesarean section with less negative birth type. Most of the women who opted for the cesarean section were satisfied and emphasized the desire for this type of birth in the next pregnancies ${ }^{(20)}$.

The lack of accurate information about vaginal birth, as well as the lack of recognition of the techniques that help in the safe and comfortable progression of labor, can make it difficult to maintain 
the preference for this type of birth, from the beginning to the end of gestation, in this study. In addition, medical and doctorpregnancy decisions were frequently identified as determinants of choice for cesarean section, contributing to the increase in rates of this frequent and easily adopted procedure ${ }^{(16)}$. Recognizing the determining factors for the changes in the decision-making process by the type of birth constitutes an essential practice for the definition of a healthy birth care line, with the preparation of the institutions that will receive the pregnant women and the professionals responsible for birth care.

In most public and private institutions, cesarean birth rates are associated with surgeries intentionally scheduled and/or decided within the first few hours after hospital admission after commencement of labor, such as elective cesarean section or elective intrapartum cesarean section $^{(16)}$. Increase occurrence of this procedure is also related to the desire of women for this type of birth supported by the doctor, either by the convenience of scheduling the procedure, by the viability of having the same health professional who accompanied the prenatal care, by the preference of the family or by the perception that cesarean section is better for the mother and the newborn, aspects evidenced in the literature ${ }^{(13-14)}$.

A Uruguayan study has shown that the doctor's economic benefit and the woman's request contributed to the increase in rates of cesarean birth, especially the private health sector. It was identified that maternity hospitals using high technology, with medical-centered care, were located mainly in the United States, France and Brazil, while the Netherlands had a womancentered care with the presence of midwives and a low number of interventions during the care ${ }^{(21)}$.

Another study on the risks of cesarean without accurate indications in the United States investigated factors associated with the maternal mortality ratio from 2005 to 2014 , showing that the increasing indication of cesarean section was significant for the increase of this indicator ${ }^{(22)}$.

For the newborn, there is evidence that the consequences of unintended cesarean section can detract from essential healthrelated actions. A study conducted in Bangladesh found that babies born by cesarean section were $67 \%$ less likely to initiate breastfeeding early than vaginal deliveries, resulting from delay in skin-to-skin contact between mother and baby, maternal conditions after cesarean section ${ }^{(23)}$. Thermal care and facilitation of early skin-to-skin contact between the mother and the newborn are fundamental for the promotion of breastfeeding, even in the first hour after birth, thus contributing to the success of this practice ${ }^{(24)}$.

As seen in this study, the biomedical model of care for pregnancy and birth, based on the risks that vaginal birth can cause and presents cesarean section as a model of security and modernity, is characterized by the lack of centrality and protagonism of women that generally does not discuss with the doctor what would be best for her and her child, accepting the conduct without questioning, overestimating medical opinion regarding the choice and final indication of the type of birth ${ }^{(3,25)}$.

From the discourses of this study, it was possible to understand that the experiences of family members interfered in the choice of the pregnant woman in the type of birth, especially when they were vaginal deliveries. A study carried out with 25 puerperal women at the University Hospital of Mato Grosso do Sul State, Brazil, evidenced decision-making based on previous experiences, and women who had previously had vaginal birth had a desire for this type of birth, in the case of cesarean section. Due to the lack of accurate prenatal information, and with the current model of care in the public and private sectors, insecurity and frustration about previous experiences are common, and so often the influence is negative ${ }^{(26)}$. It is recommended to provide evidence-based information on the types of births and births for pregnant women during prenatal care, aiming at the inclusion and active participation of women in the decision process, respecting the clinical condition as well as cultural characteristics and autonomy ${ }^{(24)}$.

\section{Study limitations}

Among the limitations, the difficulty of early capture of the pregnant women included in the study is highlighted, resulting in proximity between the two interview moments ( $M 1$ and $M 2$ ). This may have contributed to the low variability in the type of birth referred to as desired by participants.

\section{Contributions to the fields of Nursing, Health or Public Policies}

The results of this study reinforce the need for recognition by nurses and other members of the health team of the central role of the pregnant/parturient in the pregnancy-puerperal cycle, including assisting the active and enlightened participation of them and their families. In this sense, the offer of specific educational activities in a group of pregnant women may be important, since it has the potential to demystify some aspects of vaginal birth, especially related to the fear of pain and its unpredictability.

\section{FINAL CONSIDERATIONS}

This study's findings confirm that the decision on the type of birth involves, besides the preferences of the pregnant woman, also those of the family and those of the doctor, being identified the main aspects that influence that process. By and large, in early pregnancy, pregnant women were divided between the preference for vaginal birth because of its advantages for the mother and the baby, and cesarean section, especially since it involved less pain. At that first moment, there were also doubts as to the type of birth desired. At the end of the day, there was no doubt, being more preferred the cesarean section. This preference was still closely linked to the perceptions and expectations that, in this type of procedure, the pregnant woman is saved from pain and she and her baby are given greater security, contradicting the evidence contained in both the scientific literature and related public policies.

Provision of educational groups, especially organized in the style of 'Round Conversations', aimed at pregnant women and their families, may play an important role in the empowerment of women in choosing the type of birth, since the rejection overcoming to vaginal birth will go through the deconstruction of cesarean section as an ideal model for the birth and by the valuation of labor assisted in a safe and humanized way as an essential mechanism for the health of mothers and newborns. 


\section{REFERENCES}

1. Sanfelice CFO, Abbud FSF, Pregnolatto OS, Silva MG, Shimo AKK. Do parto institucionalizado ao parto domiciliar. Rev Rene. 2014;15(2):36270. doi: 10.15253/2175-6783.2014000200022

2. Velho MB, Santos EKA, Collaço VS. Parto normal e cesárea: representações sociais de mulheres que os vivenciaram. Rev Bras Enferm. 2014;67(2):282-9. doi: 10.5935/0034-7167.20140038

3. Copelli FHS, Rocha L, Zampieri MFM, Gregório VRP, Custódio ZAO. Determinants of women's preference for cesarean section. Texto Contexto Enferm. 2015;24(2):336-43. doi: 10.1590/0104-07072015000430014

4. O'Donovan C, O'Donovan J. Why do women request an elective cesarean delivery for non-medical reasons? a systematic review of the qualitative literature. Birth. 2018;45:109-19. doi: 10.1111/birt.12319

5. Chen SW, Hutchinson AM, Nagle C, Bucknall TK. Women's decision-making processes and the influences on their mode of birth following a previous caesarean section in Taiwan: a qualitative study. BMC Pregnancy Childbirth. 2018;18:31. doi: 10.1186/s12884-018-1661-0

6. Cesar JA, Sauer JP, Carlotto K, Montagner ME, Mendoza-Sassi RA. Cesarean section on demand: a population-based study in Southern Brazil. Rev Bras Saúde Matern Infant. 2017;17(1):99-105. doi: 10.1590/1806-93042017000100006

7. World Health Organization (WHO). WHO recommendations on antenatal care for a positive pregnancy experience [Internet]. Geneva: WHO; 2016 [cited 2018 Feb 8]. Available from: http://apps.who.int/iris/bitstream/10665/250796/1/9789241549912-eng.pdf?ua=1

8. Ministério da Saúde (BR). Secretaria de Atenção à Saúde. Departamento de Atenção Básica. Atenção ao pré-natal de baixo risco [Internet]. Brasília: Ministério da Saúde; 2012 [cited 2016 Jun 2]. (Cadernos de Atenção Básica, n 32). Available from: http://bvsms.saude.gov.br/bvs/ publicacoes/cadernos_atencao_basica_32_prenatal.pdf

9. Lefevre F, Lefevre AMC. Pesquisa de representação social, um enfoque qualiquantitativo: a metodologia do discurso de sujeito coletivo. $2 a$ ed. Brasília: Liber Livro Editora; 2012.

10. Minayo MCS. O desafio do conhecimento: pesquisa qualitativa em saúde. 14a ed. São Paulo: Hucitec; 2014.

11. Duarte SJH, Mamede MV, Andrade SMO. Opções teórico-metodológicas em pesquisas qualitativas: representações sociais e discurso do sujeito coletivo. Saúde Soc. 2009;18(4):620-6. doi: 10.1590/S0104-12902009000400006

12. Pinheiro BC, Bittar CML. Expectativas, percepções e experiências sobre o parto normal: relato de um grupo de mulheres. Fractal, Rev Psicol. 2013;25(3):585-602. doi: 10.1590/S1984-02922013000300011

13. Domingues RMSM, Dias MAB, Pereira MN, Torres JA, D'Orsi E, Pereira APE, et al. Process of decision-making regarding the mode of birth in Brazil: from the initial preference of women to the final mode of birth. Cad Saúde Pública. 2014;30(Supl 1):S1-16. doi: 10.1590/0102-311X00105113

14. Mazzoni A, Althabe F, Gutierrez L, Gibbons L, Liu NH, Bonotti AM, et al. Women's preferences and mode of delivery in public and private hospitals: a prospective cohort study. BMC Pregnancy Childbirth. 2016;16:34. doi: 10.1186/s12884-016-0824-0

15. Richard F, Zongo S, Ouattara F. Fear, guilt, and debt: an exploration of women's experience and perception of cesarean birth in Burkina Faso, West Africa. Int J Womens Health. 2014;6:469-78. doi: 10.2147/IJWH.S54742

16. Ministério da Saúde (BR). Universidade Estadual do Ceará. Cadernos Humaniza SUS, Volume 4 - Humanização do parto e do nascimento [Internet]. Brasília: Ministério da Saúde; 2014 [cited 2016 Jun 2]. Available from: http://www.redehumanizasus.net/sites/default/files/ caderno_humanizasus_v4_humanizacao_parto.pdf

17. Souza ENS, Aguiar MGG, Silva BSM. Métodos não farmacológicos no alívio da dor: equipe de enfermagem na assistência a parturiente em trabalho de parto e parto. Enferm Rev [Internet]. 2015 [cited 2016 Jun 2];18(2):42-56. Available from: http://periodicos.pucminas.br/index. php/enfermagemrevista/article/viewFile/11693

18. Medeiros J, Hamad GBNZ, Costa RRO, Chaves AEP, Medeiros SM. Métodos não farmacológicos no alívio da dor de parto: percepção de puérperas. Espaç Saúde [Internet]. 2015 [cited 2016 Jun 2];16(2):37-44. Available from: http://arquivos.info.ufrn.br/arquivos/201608205736d e31129168663d5038d03/20717-100220-1-PB.pdf

19. Pereira RR, Franco SC, Baldin N. A dor e o protagonismo da mulher na parturição. Rev Bras Anestesiol. 2011;61(3):376-88. doi: 10.1590/ S0034-70942011000300014

20. Stützer PP, Berlit S, Lis S, Schmahl C, Sütterlin M, Tuschy B. Elective Caesarean section on maternal request in Germany: factors affecting decision making concerning mode of delivery. Arch Gynecol Obstet. 2017;295(5):1151-6. doi: 10.1007/s00404-017-4349-1

21. Cóppola F. Cesáreas en Uruguay. Rev Med Urug [Internet]. 2015 [cited 2018 Mar 23];31(1):7-14. Available from: http://www.scielo.edu.uy/ scielo.php?script=sci_arttext\&pid=S1688-03902015000100002

22. Moaddab A, Dildy GA, Brown HL, Bateni ZH, Belfort MA, Sangi-Haghpeykar H, et al. Health Care Disparity and State-Specific PregnancyRelated Mortality in the United States, 2005-2014. Obstet Gynecol. 2016;128(4):869-75. doi: 10.1097/AOG.0000000000001628

23. Singh K, Khan SM, Carvajal-Aguirre L, Brodish P, Amouzou A, Moran A. The importance of skin-to-skin contact for early initiation of breastfeeding in Nigeria and Bangladesh. J Glob Health. 2017;7(2):020505. doi: 10.7189/jogh.07.020505

24. Ministério da Saúde (BR). Comissão Nacional de incorporação de tecnologia no SUS. Diretrizes de Atenção à Gestante: a operação cesariana. Relatório de recomendação [Internet]. Brasília: Ministério da Saúde; 2015 [cited 2018 Mar 23]. Available from: http://conitec.gov.br/images/ 
Consultas/Relatorios/2015/Relatorio_PCDTCesariana_CP.pdf

25. Amorim MMR, Souza ASR, Porto AMF. Indicações de cesariana baseadas em evidências: parte I. Femina [Internet]. 2010 [cited 2016 Jun 02];38(8):417-22. Available from: http://bhpelopartonormal.pbh.gov.br/estudos_cientificos/arquivos/cesariana_baseada_evidencias_parte_l.pdf

26. Nascimento RRP, Arantes SL, Souza EDC, Contrera L, Sales APA. Escolha do tipo de parto: fatores relatados por puérperas. Rev Gaúcha Enferm. 2015;36(esp);119-26. doi: 10.1590/1983-1447.2015.esp.56496 